\title{
Prevalence of Urinary Schistosomiasis among Secondary School Students in Ifedore Local Government, Ondo State, Nigeria
}

\author{
Akinneye $\mathrm{JO}^{1}$, Fasidi $\mathrm{MM}^{2}$, Afolabi $\mathrm{OJ}^{1^{*}}$ and Adesina $\mathrm{FP}^{1}$ \\ ${ }^{1}$ Department of Biology, Federal University of Technology, Nigeria \\ ${ }^{2}$ Ondo State School of Nursing, Nigeria
}

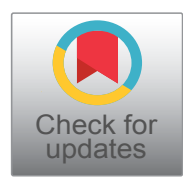

*Corresponding author: Afolabi JO, Department of Biology, Federal University of Technology, Nigeria, E-mail: josephakinneye@yahoo.co.uk

\begin{abstract}
Schistosomiasis (Bilharziasis) is water borne parasitic disease caused by a blood fluke (trematode) of the genus Schistosoma. Adult schistosome worms live in mammalian host and the intermediate host is aquatic snail. Schistosomiasis ranks second to malaria in terms of prevalence and persistence with grave public health and socio-economic importance in endemic communities. This study assessed the prevalence of urinary schistosomiasis among students of five selected secondary schools in Ifedore Local Government of Ondo State. A total of four hundred and thirteen (413) students urine samples were examined for eggs of Schistosoma and 57 students $(13.8 \%)$ excreted eggs of S. haematobium in their urine. There was no significant difference $(P>0.05)$ in the prevalence of urinary infection between genders. Meanwhile, the prevalence of hematuria was significantly higher $(P<0.05)$ in male $(22.7 \%)$ than the female gender $(14.4 \%)$. The highest prevalence was observed among age group $16-18$ years $(21.7 \%)$ while the least prevalence was observed in age group 10-12 years $(11.5 \%)$. The study confirmed the prevalence of S. haematobium in the study area. Proper sanitation, water control and snail elimination as well as community-based programs are highly needed to reduce the prevalent of urinary schistosomiasis in the study area.
\end{abstract}

\section{Keywords}

Schistosomiasis, Hematuria, S. haematobium

\section{Introduction}

Schistosomiasis also known as bilharziasis, is waterborne disease caused by parasites of the genus Schistosoma, a digenic trematode that reside in the blood vessels of man and livestock four species of this Schis- tosoma are common to man; S. mansoni, S. haematobium, S. japonicum and S. intercalatum. Schistosomiasis is one of the most important neglected tropical diseases in terms of public health affecting more than $\mathbf{2 0 0}$ million people and is second only to malaria in terms of public health importance, killing an estimated 280,000 people each year in the African region alone [1]. S. haematobium is the causative agent of urinary schistosomiasis and it is most prevalent in Africa (National Travel Health Network and Centre) [2].

Urinary schistosomiasis leads to a variety of clinical manifestations as hematuria; The presence of blood cells in urine. Other associated features are dysuria and suprapubic pain. In sub-Saharan Africa, S. haematobium infection is estimated to cause 70,32,18 and 10 million cases of hematuria, dysuria, bladder-wall pathology and major hydronephrosis respectively [3]. Other health impacts associated with the disease are risk of anemia, bladder cancer, nutritional deficiencies, delay puberty in children, stunted growth in children and impairment of cognitive development in infected individuals as well as decreasing physical activity, school performance, work capacity and productivity $[4,5]$. The highest prevalence and intensities usually found in school-age children, adolescent and young adults [6].

Several environmental and socio-economic factors have been identified to be responsible for the continued persistence of intestinal parasitic infection in children. Some of these factors include poor sanitary conditions,

Citation: Akinneye JO, Fasidi MM, Afolabi OJ, Adesina FP (2018) Prevalence of Urinary Schistosomiasis among Secondary School Students in Ifedore Local Government, Ondo State, Nigeria. Int J Trop Dis 1:004.

Accepted: August 02, 2018; Published: August 04, 2018

Copyright: (c) 2018 Akinneye JO, et al. This is an open-access article distributed under the terms of the Creative Commons Attribution License, which permits unrestricted use, distribution, and reproduction in any medium, provided the original author and source are credited. 
unhygienic practices, lack of potable water, poor housing and poverty $[7,8]$. The conditions lead to continued exposure to the causal parasites and thus high rates of re-infection [9]. This infection is also associated with rural agricultural and other human activities around the freshwater bodies such as swimming, fishing, washing and bathing in ponds, rivers and dams, where the snail intermediate hosts breed. The tradition of African rural women in company of their children to wash household utensils in nearby stagnant water is not left out in socio-economic factors.

School age children were thought to have frequent water contact that would make them more vulnerable to schistosomiasis, and hence this age group would be associated more frequently with schistosomiasis problems $[10,11]$. Schistosome infections are usually at their peak in late childhood to early adulthood. In some parts of Africa, the onset of hematuria due to urinary schistosomiasis is very common in adolescent boys, and due to lack of knowledge, it is seen as a normal phenomenon in some communities [12]. Hence, this study aimed to assess the prevalence of urinary schistosomiasis among school pupils in Ifedore Local Government Area of Ondo State, Nigeria.

\section{Materials and Methods}

\section{Study design}

A cross-sectional study was conducted among students of five (5) selected secondary schools in Ifedore Local Government Area focusing on determining the prevalence of urinary schistosomiasis in the study area.

\section{Study area}

The study was carried out among students of selected secondary schools in Ifedore Local Government Area of Ondo State. Ifedore Local Government is one of the eighteen Local Government Areas in Ondo State. The Local Government Area with headquarters in Igbara Oke is bounded to the North and East by Akure South Local Government Area to the south by Osun State, to the west by Ekiti State (Figure 1). Ondo State is located within longitude $4.89^{\circ} \mathrm{E}$ and latitude $6.89^{\circ} \mathrm{N}$. Five secondary schools were randomly selected from the five selected towns that make up the Local Government Area. These schools are: Anglican Grammar School Igbara Oke with student population of 835; The Apostolic High School, Ilara Mokin with student population of 768; Ayo Grammar School Ipogun with a student population of 324; Anglican Grammar School ljare with student population of 644 and Community High School Isarun with student population of 220. The major water sources in all these areas were springs, stream and rivers, which are for domestic, occupational and recreational purposes such as drinking, bathing, washing, farming and swimming.

\section{Sample and sampling technique}

Sample: The required sample size was determined using single population proportion formula and assuming a $58.1 \%$ proportion of urinary schistosomiasis from previous study by Ekpo, et al. [13].

$$
\begin{aligned}
& n=p(1-p)\left(\frac{Z}{E}\right)^{2} \\
& \mathrm{n}=\text { sample size }
\end{aligned}
$$

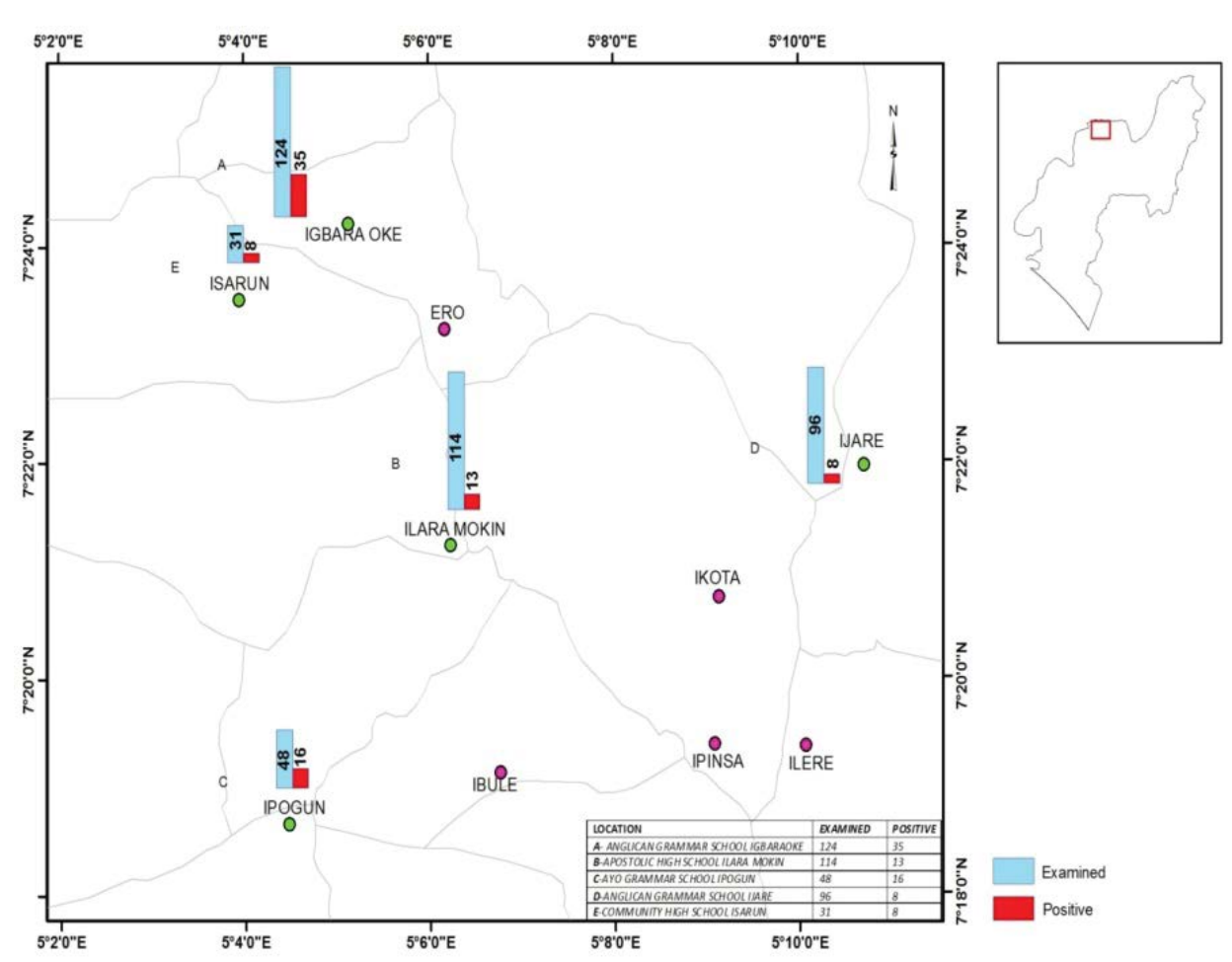

Figure 1: Map of Ifedore local government area, Ondo State, Nigeria showing the sampled towns using Geographic Information System (GIS) (2017). 
$Z$ is the confidence level $(Z=1.96$ for $95 \%)$

$E$ is the desired margin of error (0.05)

$\mathrm{P}=$ proportion of schistosomiasis in the population from previous study $=58.1 \%=0.581$

$$
n=0.581(1-0.581)\left(\frac{1.96}{0.05}\right)^{2}
$$

$\mathrm{n}=375$

Therefore with $10 \%$ attrition rate, 413 students whose age range from 10-18 years were examined from the five selected secondary schools to participate in the study.

\section{Urinalysis}

Urine samples were collected between 09:00 and 12:00 h. Each pupil was given a clean, dry, universal bottle to urinate in with emphasis on the last drop. The urine samples collected were transported in ice packs to the Central Laboratory of Ondo State Primary Health care board, Oke Eda for analysis. Laboratory analysis of the urine was done using the centrifugation method. $10 \mathrm{mls}$ of urine was centrifuged at 1,500 rpm for 5 minutes and the residue was examined under the $\times 10$ objective of the microscope for the presence of terminal spine ova of S. haematobium. Eggs of S. heamatobium were counted under light microscope at low magnification. Results were expressed as the number of $S$. haematobium eggs $/ 10 \mathrm{ml}$ urine. Cases of hematuria were observed and recorded.

\section{Data analysis}

Data were analyzed statistically using Statistical Package for Social Sciences (SPSS) software version 20.0 at $P<0.05$ level of significance. The Chi square $\left(X^{2}\right)$ test was used to test possible association of infection with respect to age and sex. P-values less than 0.05 were considered statistically significant.

\section{Ethical Consideration and Informed Consent}

Before the commencement, approval was sought from the Primary Health Care Board, Oke Eda Akure, Village heads, and the principals of the schools used for the survey. Consent forms were given to the pupils to take home to their parents. Those whose parents consented were the ones recruited for the study.

\section{Results}

\section{Prevalence of urinary schistosomiasis among the se- lected students in Ifedore local government area}

In all, four hundred and thirteen (413) students from five randomly selected secondary schools in Ifedore Local Government Area of Ondo State were examined for urinary schistosomiasis and fifty seven (57) students were positive to the infection representing $13.8 \%$. Urinary schistosomiasis infections were not significantly different between gender $(p=0.093)$ even though male had higher prevalence of $16.6 \%$ than female with $10.9 \%$ but these figures were not significantly different $(p=0.093)$ (Table 1$)$.
Age prevalence of schistosomiasis showed that 24 students that were within the age range 13-15 years of age that participated in the study tested positive for schistosomiasis with the percentage prevalence of $16.3 \%$. However, the highest prevalence of $21.7 \%, n=5$ was observed in age group 16-18 years while the least prevalence of $11.5 \%, \mathrm{n}=28$ was observed in age group 10-12 years (Table 2). Meanwhile, Chi-square $\left(\chi^{2}\right)$ analysis of the data showed that the age of the students has nothing to do with the prevalence of urinary schistosomiasis in secondary schools $(p=0.322)$.

\section{Prevalence of hematuria among the population examined for urinary schistosomiasis}

The result in Table 3 showed that not all the students that manifested hematuria were positive to $S$. haematobium ova. For instance 48 male students had hematuria while 35 of them were positive to urinary schistosomiasis representing $22.7 \%$ because of the presence of ova with terminal spine in their urine. Similarly, of the 29 female students that had hematuria, 22 were infected with urinary schistosomiasis (Table 3 ). The hematuria were noted to be more among the male $(22.7 \%)$ than the female gender (14.4\%).

Table 4 showed that the prevalence of hematuria varied significantly among the age groups $(P<0.05)$. The highest prevalence $(60.9 \%)$ of hematuria was observed in age group $16-18$ years while the least prevalence $(12.3 \%)$ of hematuria was observed in age group 10-12 years. Generally, it was noted that the prevalence of hematuria increases as the age of the subject increases (Table 4).

Table 1: Prevalence of urinary schistosomiasis by gender in Ifedore local government area.

\begin{tabular}{|l|l|l|l|}
\hline Gender & $\begin{array}{l}\text { Number } \\
\text { Examined }\end{array}$ & $\begin{array}{l}\text { Number } \\
\text { infected }\end{array}$ & $\begin{array}{l}\text { Percentage } \\
\text { Prevalence (\%) }\end{array}$ \\
\hline Male & 211 & 35 & 16.6 \\
\hline Female & 202 & 22 & 10.9 \\
\hline Total & $\mathbf{4 1 3}$ & $\mathbf{5 7}$ & $\mathbf{1 3 . 8}$ \\
\hline
\end{tabular}

$X^{2}=2.815, d f=1, P=0.093$.

Table 2: Prevalence of schistosomiasis among age groups in Ifedore local government area of Ondo State.

\begin{tabular}{|l|l|l|l|}
\hline $\begin{array}{l}\text { Age Group } \\
\text { (Years) }\end{array}$ & $\begin{array}{l}\text { Number } \\
\text { Examined }\end{array}$ & $\begin{array}{l}\text { Number } \\
\text { Positive }\end{array}$ & $\begin{array}{l}\text { Prevalence } \\
(\%)\end{array}$ \\
\hline $\mathbf{1 0 - 1 2}$ & 243 & 28 & 11.5 \\
\hline $\mathbf{1 3 - 1 5}$ & 147 & 24 & 16.3 \\
\hline $\mathbf{1 6 - 1 8}$ & 23 & 5 & 21.7 \\
\hline Total & $\mathbf{4 1 3}$ & $\mathbf{5 7}$ & $\mathbf{1 3 . 8}$ \\
\hline
\end{tabular}

$X^{2}=2.266, d f=2, P=0.322$.

Table 3: Prevalence of Hematuria by gender.

\begin{tabular}{|l|l|l|l|l|}
\hline Gender & $\begin{array}{l}\text { Number } \\
\text { Examined }\end{array}$ & $\begin{array}{l}\text { Number with } \\
\text { Hematuria }\end{array}$ & $\begin{array}{l}\text { Number } \\
\text { Infected }\end{array}$ & $\begin{array}{l}\text { Prevalence } \\
\text { (\%) }\end{array}$ \\
\hline Male & 211 & 48 & 35 & 22.7 \\
\hline Female & 202 & 29 & 22 & 14.4 \\
\hline Total & $\mathbf{4 1 3}$ & $\mathbf{7 7}$ & $\mathbf{5 7}$ & $\mathbf{1 8 . 6}$ \\
\hline
\end{tabular}

$X^{2}=0.076, d f=1, P=0.045$. 
Result presented in Table 5 showed the prevalence of urinary schistosomiasis among the selected secondary schools. The prevalence was observed to vary significantly among the secondary schools $(P<0.05)$. The highest prevalence of the disease was observed in Ayo Grammar School Ipogun (33.3\%) while the least prevalence (5.2\%) was observed in Anglican Grammar School ljare. In addition, 20.9\%, 6.1\% and 9.7\% prevalence were recorded in Anglican Grammar School Igbara Oke, the Apostolic High School Igbara Oke and Community High School Isarun respectively.

Table 5 also showed the prevalence of urinary schistosomiasis in relations to distance from the transmission site (river). Ayo Grammar School Ipogun with the highest prevalence of $33.3 \%$ had the shortest distance $(<1.0 \mathrm{~km})$ from the Ipogun river (transmission site) while Anglican Grammar School ljare with the lowest prevalence of $6.1 \%$ had the longest distance $(<10.0 \mathrm{~km})$ to the transmission site. The result showed that there was inverse relationship between prevalence of infection and distance from the river.

\section{Discussion}

From 413 students examined, 57 tested positive to urinary schistosomiasis with the $13.8 \%$ prevalence. Considering the pathology of the parasites (S. haematobi$u m$ ) and the morbidity associated with the disease, this prevalence $(13.8 \%)$ is considered to be of public health importance. Similar prevalence (11.2\%) was recorded by Ekpo, et al. [13] in a study conducted among pre-school children in rural community near Abeokuta in Nigeria.

Prevalence of $13.8 \%$ is considered low by WHO [14] nonetheless infection is wide spread in the area. The low prevalence obtained was in accordance with other studies in Nigeria such as Ekejindu, et al. [15] in Anambra State (11.8\%), Akogun [16] in Malumfashi, Bauchi State (17\%), Istifanus, et al. [17] in Malumfashi (17\%),

Table 4: Prevalence of Hematuria among age cohorts in Ifedore local government area.

\begin{tabular}{|l|l|l|l|l|}
\hline $\begin{array}{l}\text { Age Group } \\
\text { (Years) }\end{array}$ & $\begin{array}{l}\text { Number } \\
\text { Examined }\end{array}$ & $\begin{array}{l}\text { Number with } \\
\text { Hematuria }\end{array}$ & $\begin{array}{l}\text { Number } \\
\text { Infected }\end{array}$ & $\begin{array}{l}\text { Prevalence } \\
(\%)\end{array}$ \\
\hline $\mathbf{1 0 - 1 2}$ & 243 & 30 & 28 & 12.3 \\
\hline $\mathbf{1 3 - 1 5}$ & 147 & 33 & 24 & 22.4 \\
\hline $\mathbf{1 6 - 1 8}$ & 23 & 14 & 5 & 60.9 \\
\hline Total & $\mathbf{4 1 3}$ & $\mathbf{7 7}$ & $\mathbf{5 7}$ & $\mathbf{1 8 . 6}$ \\
\hline
\end{tabular}

$X^{2}=19.207, \mathrm{df}=2, \mathrm{P}=0.01$.
Okoli, Odaibo [18] in Ibadan (17.4\%) and Fajewonyomi, Afolabi [19] in Ile-Ife, Oyo State (20.50\%).

The prevalent rate of the infection in this area suggests repeated exposure to infection by students examined as it had also been documented by Oniya and Odaibo [20]. Interaction with some students examined revealed that a number of the students still bath and drink from some of the rivers (like Apomu river and Ipogun river) in the area that had been found out to serve as reservoir for the host organism (S. haematobium) and intermediate host (Bulinus spp) of this infection [21].

It is important to note that the level of prevalence of the infection established in this study is $18.6 \%$ similar result (18.0\%) had already been established in the Local government in previous study by Oniya and Olofintoye [22]. However, it is expected that the prevalence should have drastically reduced since the time of Oniya and Olofintoye [22], however this is far from what is shown by the result of the study. The reason for this might be ingenuity in effort of the government and other agencies at reducing the scourge of this infection, other reason might be due to the ignorance of the people about the mode of transmission of the disease in their communities. Except for Oniya, et al. [21] study in Ifedore Local Government Area of Ondo State, other studies in Nigeria had found out higher prevalence of schistosomiasis among their study population as compared with what was found out in this study. For instance, Odaibo, et al. [23] recorded prevalence of $30.4 \%$ in Ondo State; Akinwale, et al. [24] recorded prevalence of $54.6 \%$ in their study in Ogun State and Ugbomoiko, et al. [25] recorded prevalence of $62.0 \%$ among people in two peri-urban communities (Eko-ende and Ore) in Osun State, South Western Nigeria. Also, Ozowara, et al. [26] documented $46.18 \%$ prevalence of schistosomiasis among school children in a Local Government Area in Ebonyi State while a more recent study conducted by Singh and Muddasiru [27] among children in riverine areas of Sokoto State recorded the prevalence rate of $60.8 \%$.

The results further showed that there was no significant difference $\left(\chi^{2}=2.82 ; P>0.05\right)$ in the prevalence of schistosomiasis between gender. Meanwhile the pathological effect of the parasite was more pronounced among the male subjects (22.7\%) than the female subjects (14.4\%). This suggests that the pathology associat-

Table 5: Prevalence of schistosomiasis among selected secondary schools in Ifedore local government area.

\begin{tabular}{|l|l|l|l|l|}
\hline School & $\begin{array}{l}\text { Distance of the river to } \\
\text { the stream (km) }\end{array}$ & $\begin{array}{l}\text { Number } \\
\text { examined }\end{array}$ & $\begin{array}{l}\text { Number } \\
\text { positive }\end{array}$ & Prevalence (\%) \\
\hline Anglican Grammar School Igbara Oke & $<2.0$ & 124 & 26 & 20.9 \\
\hline The Apostolic High School Igbara Oke & $<5.0$ & 114 & 7 & 6.1 \\
\hline Ayo Grammar School Ipogun & $<1.0$ & 48 & 16 & 33.3 \\
\hline Anglican Grammar School, Ijare & $<10.0$ & 96 & 5 & 5.2 \\
\hline Community High School Isarun & $<3.0$ & 31 & 3 & 9.7 \\
\hline Total & $<\mathbf{2 1} \mathbf{~ k m}$ & $\mathbf{4 1 3}$ & $\mathbf{5 7}$ & $\mathbf{1 3 . 8}$ \\
\hline
\end{tabular}

$X^{2}=23.563, d f=4, P=0.01$. 
ed with $S$. haematobium as presented by hematuria is a function of intensity and frequency of exposure. The male subjects are known to visit the rivers more than the female.

The results indicated that students who tested positive for schistosomiasis were also at greater risk of hematuria. This implies that the hematuria test may be a very useful diagnostic tool for the detection of Schistosoma haematobium infections. The association between Schistosoma haematobium and hematuria had also been reported by Anosike, et al. [28] and Vender Warf, et al. [3]. There are contradictory reports regard to gender prevalence as reported by Singh and Muddasiru [27], that schistosomiasis was more pronounced among male (79.59\%) compared to the female population (20.41\%) in Sokoto. Similarly, result of Mbata, et al. [29] in a study conducted in a Local Government Area in Benue State reported that schistosomiasis was higher among female (152 (23.13\%)) than male (148 (22.52\%)), this is also corroborated by report of Nkegbe [30] in Ghana.

The prevalence of schistosomiasis among the age groups showed that the disease increases as the age group increases. The confirmation that age group is one of the predisposing factors that exposed the subjects to the disease has also been reported by Abebe, et al. [31]. The prevalence among the age group $10-18$ years were also supported by Singh and Muddasiru [27] who found out that the prevalence of schistosomiasis was significantly higher among children within age range 9 to 12 years of age. This study however, found out that there was linear relationship between age and prevalence of schistosomiasis infection among the students examined.

The pattern of human water contact activity was dependent on the nature, accessibility and suitability of each site. The closeness of the schools to the host stream and the frequent exposure to the stream contributed to high prevalence of urinary schistosomiasis among the students. Chidi, et al. [32] revealed that the respondents who were living closer to rivers/streams and ponds were more at risk of getting schistosomiasis than those living far. However, Imran, et al. [33] suggested that the risk of infection may not depend on proximity to the river but there could be possibility of scattered water bodies as a source of infections of schistosomiasis, that are even more suitable for harboring snails vector than the closest river. Swimming activities were observed at the closest site to the study area by the students. In general, washing limbs, fetching water, clothes and farm tools as well as farm products were found to be activities of importance, in the transmission of schistosomiasis.

\section{Conclusion}

Considering the prevalence observed in the study area, it showed that urinary schistosomiasis is still a dis- ease of public health importance in Ifedore Local Government Area. Therefore, more researches focusing on vector control should be carried out in this area. Similarly, presence of hematuria among the infected students calls for mass chemotherapy in the community. However, the chemotherapy will not be effective unless the individuals stop bathing, swimming and washing in contaminated water. To achieve this, government should provide potable water such as bore holes and pipe-borne water in the community to reduce contact with the contaminated river.

\section{Acknowledgement}

Special thanks to the entire staff of Ondo State School of Nursing, selected schools and Ondo State Central Laboratory, thank you so much.

\section{References}

1. (2011) CDC The burden of schistosomiasis. Global Health-Division of Parasitic Diseases and Malaria.

2. National Travel Health Network and Centre (NaTHNaC) (2014) Schistosomiasis.

3. Van der Werf MJ, de Vlas SJ, Brooker S, Looman CW, Nagelkerke NJ, et al. (2003) Quantification of clinical morbidity associated with schistosome infection in sub-Saharan Africa. Acta Trop 86: 125-139.

4. Stephenson $L$ (1993) The impact of schistosomiasis on human nutrition. Parasitology 107: S107-S123.

5. World Health Organization (2002) Prevention and control of schistosomiasis and soil-transmitted helminthiasis. WHO Technical Report Series, Geneva, 1-4.

6. Jordan P, Webbe G (1982) Schistosomiasis: Epidemiology, treatment, and control. William Heinemann Medical Books Ltd, 361.

7. Savioli L, Crompton DW, Neira M (2003) Use of anthelminthic drugs during pregnancy. Am J Obstet Gynecol 188: 5-6.

8. Amuta EU, Omudu EA, Ahmed AS (2004) Bacteriological and parasitological evidence of soil contamination in relation to sanitary facilities in selected schools in Makurdi, Nigeria. Journal of Pest, Diseases and Vector Management 5: $337-347$

9. Catherine M, Scott W, Gordon MR (2003) The global burden of the disease due to Schistosomiasis. Disease Control Priorities Project. DCPP Working Paper, 19.

10. Kassa, L, Omer A, Tafesse W, Taye T, Kebebew F, et al. (2005) Schistosomiasis: Diploma program for the Ethiopian health center team. Ethiopian Public Health Training Initiative: 8-18.

11. Bala AY, Ladan MU, Mainasara M (2012) Prevalence and intensity of urinary schistosomiasis in Abarma village, Gusau, Nigeria: A preliminary investigation. Science World Journal 7: 1-4

12. Desowitz RS (1981) Controlling the schistosomiasis at a snails' face. In: Deswitz RS, New Guinea Tapeworms and Jewish Grand Mothers: Tales of Parasites and People Norton, New York, 2.

13. Ekpo UF, Laja-Deile A, Oluwole AS, Sam-Wobo SO, Mafiana CF (2010) Urinary schistosomiasis among preschool children in a rural community near Abeokuta, Nigeria. Parasit Vectors 3: 58. 
14. World Health Organization (1985) The control of schistosomiasis. Report of WHO Expert Committee. World Health Organ Tech Rep Ser 728: 1-113.

15. Ekejindu IM, Ekejindu GOC, Andy A (2002) Scistosoma heamatobium infection and nutritional status of residents in Azi-anam, a riverine area of Anambra State, South-Eastern Nigeria. Nigerian Journal of Parasitology 23: 133-138.

16. Akogun OB (1990) Water demand and schistosomiasis among the Gumau people of Bauchi State, Nigeria. Transactions of the Royal Society of Tropical Medicine and Hygiene 84: 548-550.

17. Istifanus WA, Mohammed A, Tal KM, Mohammed DM (1990) Prevalence and intensity of Schistosoma infection among primary school children in Bauchi State Nigeria. Nigerian Journal of Parasitology 9: 55-59.

18. Okoli El, Odaibo AB (1999) Urinary schistosomiasis among school children in Ibadan, an urban community in south-western Nigeria. Trop Med Int Health 4: 308-315.

19. Fajewonyomi BA, Afolabi JS (1994) Schistosoma haematobium infection among children in primary school, lle-Ife Nigeria. Nigerian Journal of Parasitology 15: 25-29.

20. Oniya MO, Odaibo AB (2006) Re-infection patterns and predictors of urinary schistosomiasis among school pupils from a south western village in Nigeria. International Journal of Tropical Medicine 1: 173-177.

21. Oniya MO, Ishola MA, Jayeoba OD (2013) Schistosomiasis in Ipogun: Update assessment on endemicity and efficacy of praziquantel in chemotherapy. International Journal of Tropical Disease and Health 3: 37-44.

22. Oniya MO, Olofintoye LK (2009) The prevalence of urinary schistosomiasis in two endemic local government areas in Ondo State. Nigerian Journal of Parasitology 30: 147-151.

23. Odaibo AB, Adewunm CO, Olorunmola FO, Adewoyin FB, Olofintoye LK, et al. (2004) Preliminary studies on the prevalence and distribution of urinary schistosomiasis in Ondo State, Nigeria. Afr J Med Sci 33: 219-224.

24. Akinwale OP, Ajayi MB, Akande DO, Gyang PV, Adeleke
MA (2010) Urinary schistosomiasis around Oyan Reservoir, Nigeria: Twenty years after the first outbreak. Iran J Public Health 39: 92-95.

25. Ugbomoiko US (2000) Urinary schistosomiasis in Edo State. Nigerian Journal of Parasitology 21: 3-14.

26. Ozowara NL, Njoku OO, Odikamnoro OO, Uhuo C (2011) Study of the prevalence of schistosoma haematobium infection and the treatment using praziquantel among school children in Ezza north local government area of Ebonyi state, Southeast Nigeria. European Journal of Experimental Biology 1: 103-108.

27. Singh K, Muddasiru D (2014) Epidemiology of schistosomiasis in school aged children in some riverine areas of Sokoto, Nigeria. Journal of Public Health and Epidemiology 6: 197-201.

28. Anosike JC, Nwoke BE, Njoku AJ (2001) The validity of haematuria in the community diagnosis of urinary schistosomiasis infections. J Helminthol 75: 223-225.

29. Mbata T, Orji M, Oguoma VM (2008) The prevalence of urinary schistosomiasis in Ogbadibo local government area of Benue State, Nigeria. Internet Journal of Infectious Diseases $7: 1-4$

30. Nkegbe $E$ (2010) Sex prevalence of schistosomiasis among school children in five communities in the lower river Volta Basin of south eastern Ghana. Afr J Biomed Res 13: 87-88.

31. Abebe N, Erko B, Medhin G, Berhe N (2014) Clinico-epidemiological study of schistosomiasis mansoni in Waja-Timuga, District of Alamata, northern Ethiopia. Parasites and Vectors 7: 158.

32. Chidi GO, Anosike JC, Iwuala MOE (2006) Prevalence and distribution of urinary schistosomiasis in Ohaji/Egbema local government area of Imo State, Nigeria. Journal of American Science 2: 45-48.

33. Imran E, Makanga B, Nachuha S, Mpezamihigo M (2014) Prevalence and intensity of schistosomiasis in adjacent human communities along the River Kochi, West Nile Region of Uganda. International Journal of Tropical Disease and Health 4: 729-739. 